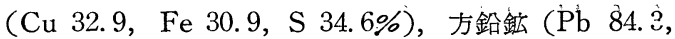
S13.3\%) をそれぞれ添加して亜鉛の浸出率に対する影 響をしらべた。黄鉄鉱は亚鉛の浸出率を著しく増大させ た（第 1 図）。黄銅鉱の添加（第 2 図）も著しい效果が あるが，これは溶出した銅イオンの作用によるものであ る。しかし黄鉄鉱の効果は, 第 2 報で述べたように鉄イ オンの効果はほとんぞないので溶出した鉄イオンによる とは考えられない。閃亚鉛鉱と黄鉄鉱が片刃粒子となつ て接触している場合は電気化学的機樌を考学ることがで きるが，この場合は別個の粒子として存在しているので 電位の差による浸出の進行を考学るのは無理である。閃 亜鉛鉱より発生した硫化水素の元素硫黄への酸化反忘の 促進に黄鉄鉱の表面が寄与寸るのではないかと考える。 方鉛鉱の添加は閃互鉛鉱の浸出を促進せず，やや抑制す る結果が得られた。合成硫化銀の添加も効果がなかつ た。

\section{5. 固溶鉄量の異なる試料の浸出の比較}

この点に関しては第 2 報でも述べたが，今回は 4 試料
（朝日，細倉，秩父，対州産）にういて比較した（第 3 図)。試料はいずれも他鉱物をほをんど含んでいないる ので，同一条件で粉砕して試料の粒度分布の差を生じな いようにした。銅を添加した場合としない場合のいずれ に打いても鉄分の高い試料ほぞ溶解しやすいことを確認 した。固溶鉄量の多い試料は微量元素の含有も増加する ので，もちろんそれらの影響も考慮する必要がある。

\section{6. 黄鉄鉱，方鉛鉱の浸出に対する硫酸銅添加 の影響}

銅イオンは閃亜鉛鉣の浸出には著しい効果を示すが， 黄鉄鉱，方鉛鉱に対してはどうであうらか。これをしら ベるために閃亜鉛鉱の浸出の場合と同様の条件で実験を おこなつた。黄鉄鉱の場合は銅は浸出を抑制する結果が えられた（第 4 図）。方鉛鉱（溶出しないので浸出とは いえないが）の場合は，少量の添加で酸化がやや増進す る傾向が見られるが，多量に添加するとむしろ抑制され る結果がえられた（第 5 図）。

これらの結果について考察を扣こなう。

\title{
3411 アンモニア性チオ硫酸ソーダ溶液への金の溶解について
}

\begin{tabular}{|c|c|c|c|}
\hline 秋田大学鈗山学部教授・工博 & 枚 & 津 & 良 \\
\hline 秋田大学鉣山学部助教授 & ○戸 & 沢 & \\
\hline
\end{tabular}

\section{1. 緒言}

複雑硫化鉱を湿式製錬によつて処理する場合の一つの 難点は鈗石中の金銀が浸出残渣に入り，回収困難なこと である。現在は浸出残渣を浮選することによつて金銀を 回収する方法が行なわれている。

Kakowski ら ${ }^{1)}$ はアンモニア性チオ硫酸溶液では

$$
2 \mathrm{Au}+4 \mathrm{~S}_{2} \mathrm{O}_{3}--+\mathrm{H}_{2} \mathrm{O}+1 / 2 \mathrm{O}_{2}
$$$$
=2 \mathrm{Au}\left(\mathrm{S}_{2} \mathrm{O}_{3}\right)_{2}---+2 \mathrm{OH}^{-}
$$

なる反応によつて金が溶解する可能性を示し $\mathrm{Cu}^{++の}$ 存 在はこの反応を促進することも示した ${ }^{2)} 。$ Plaksin ら ${ }^{3)}$ や著者ら ${ }^{4)}$ は金銀鉣や浸出残椬中の金銀を酸素加圧アン モニア浸出によつて回収することができることを示し た。また Forward ら $=$ ア加圧浸出に打いて精鉱中のイオウは $\mathrm{S}_{2} \mathrm{O}_{3} \rightarrow \mathrm{S}_{3} \mathrm{O}_{6}-$ $\rightarrow \mathrm{SO}_{4}^{-}$- のよ5に酸化されていくと述べているから, 金の漫出に（1）式を利用することは実用的な面からも 充分検討する価值があると考える。

\section{2. 実 験 方 法}

試料：金板（市販品 $99.9 \%$ ），大きさ $14.0 \times 15.5 \times$ $1.0 \mathrm{~mm}, 520^{\circ} \sim 540^{\circ} \mathrm{C}, 10$ 時間焼鈍後, 熱 $3 \mathrm{~N}-\mathrm{HCl}$, 純 水, アルコール, エーテルで洗浄し, 乾燥する。

試薬: $\mathrm{NH}_{3}$ 水, $\mathrm{Na}_{2} \mathrm{~S}_{2} \mathrm{O}_{3} \cdot 5 \mathrm{H}_{2} \mathrm{O}, \mathrm{CuSO}_{4} \cdot 5 \mathrm{H}_{2} \mathrm{O}$ は市 販一級試薬を，酸素は市販のものをそのまま使用した。

実験方法: 所要量の $\mathrm{CuSO}_{4} \cdot 5 \mathrm{H}_{2} \mathrm{O}$ を精科し, 濃 $\mathrm{NH}_{3}$ 水之純水で溶解した後, $1 \mathrm{M}-\mathrm{Na}_{2} \mathrm{~S}_{2} \mathrm{O}_{3}$ 溶液を所要量加え 純水をもつて $250 \mathrm{cc}$ としたものを溶媒とした。電磁誘
導回転式オートクレーブ（容量 $500 \mathrm{cc}$ ）を用い，精科せ る金板をテフロン糸でオートクレーブ内に將垂し，上記 溶媒 $200 \mathrm{cc}$ を装入し，密閉する。所要温度に達した 後, 酸素を所要圧力導入し，攪拌を開始し，所要時間反 応せしめる。反沈後空泠し, 金板を熱 $3 \mathrm{~N}-\mathrm{HCl}$, 純水, アルコール, エーテルで洗浄し, 重量減から溶解量を求 めた。

\section{3. 実 験 結 果}

温度の影響: 液組 成 $0.25 \mathrm{~mol} / l \mathrm{Na}_{2} \mathrm{~S}_{2} \mathrm{O}_{3}, 0 \sim 0.112$ $\mathrm{mol} / l \mathrm{CuSO}_{4}, 1 \mathrm{~mol} / l \mathrm{NH}_{3}, P_{\mathrm{O}_{2}} 2 \mathrm{~kg} / \mathrm{cm}^{2}$, 回転数 200 $\mathrm{rpm}$, 反忘時間 3 時間なる条件で温度を $20^{\circ} \sim 180^{\circ} \mathrm{C}$ ま で変えて金の溶解量を求めると， $65^{\circ} \mathrm{C}$ 来では溶解量は増

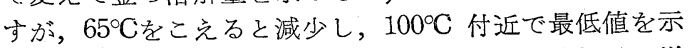
し, 温度がさらに高くなると $140^{\circ} \mathrm{C}$ を゙再び溶解量を増 し，140Cをこえると減少する。

酸素分圧の影響: 液組成 $0.25 \mathrm{~mol} / l \mathrm{Na}_{2} \mathrm{~S}_{2} \mathrm{O}_{3}, 0.04$ $\mathrm{mol} / l \mathrm{CuSO}_{4}, 1 \mathrm{~mol} / l \mathrm{NH}_{3}$, 温度 $65^{\circ} \mathrm{C}$, 反流時間 3 時 間，回転数 $200 \mathrm{rpm}$ なる条件で $P_{\mathrm{O}_{2}} 0.2 \sim 10 \mathrm{~kg} / \mathrm{cm}^{2}$ の 範囲で実験した結果, 溶解量は $P_{\mathrm{O}_{2}} 1 \mathrm{~kg} / \mathrm{cm}^{2}$ で最高值 を示した。

攪找の影響 : 液組成 $0.25 \mathrm{~mol} / l \mathrm{Na}_{2} \mathrm{~S}_{2} \mathrm{O}_{3}, 0.04 \mathrm{~mol} / l$ $\mathrm{CuSO}_{4}, 1 \mathrm{~mol} / l \quad \mathrm{NH}_{3}, P_{\mathrm{O}_{2}} 2 \mathrm{~kg} / \mathrm{cm}^{2}, 65^{\circ} \mathrm{C}$, 反応時間 3 時間なる条件で回転数を 0 ～600 r pm に変えた結果， 回転数 $200 \mathrm{rpm}$ がもつともよく溶解し，これ以上回転数 を增すと溶解量は低下寸る。

$\mathrm{NH}_{3}$ の影響 : 液組成 $0.25 \mathrm{~mol} / l \mathrm{Na}_{2} \mathrm{~S}_{2} \mathrm{O}_{3}, 0.04 \mathrm{~mol} / l$ 
$\mathrm{CuSO}_{4}, P_{\mathrm{O}_{2}} 2 \mathrm{~kg} / \mathrm{cm}^{2}$, 温度 $65^{\circ} \mathrm{C}$, 反応時間 3 時間, 回転数 $200 \mathrm{rpm}$ なる条件で $\mathrm{NH}_{3}$ を. $0 \sim 5 \mathrm{~mol} / l$ の範囲 で変化させると, $0.5 \mathrm{~mol} / \mathrm{l} \mathrm{NH}_{3}$ のとき最高溶解量を示 した。

$\mathbf{C u S O}_{4}, \mathbf{N a}_{2} \mathbf{S}_{2} \mathbf{O}_{3}$ の影響：液組成 $1 \mathrm{~mol} / l \mathrm{NH}_{3}, 0 \sim$ $0.12 \mathrm{~mol} / l \mathrm{CuSO}_{4}, 0.15 \sim 0.48 \mathrm{~mol} / l \mathrm{Na}_{2} \mathrm{~S}_{2} \mathrm{O}_{3}, P_{\mathrm{O}_{2}} 2 \mathrm{~kg}$ $/ \mathrm{cm}^{2}$, 温度 $65^{\circ} \mathrm{C}$, 反応時間 3 時間, 回転数 $200 \mathrm{rpm}$ なる 条件で実験を行なつた結果 $\mathrm{Na}_{2} \mathrm{~S}_{2} \mathrm{O}_{3}$ 濃度を一定にした ときは $\mathrm{CuSO}_{4}$ 添加量によつて金の溶解量は極大を示す。 また $\mathrm{CuSO}_{4}$ 添加量を一定にすると, $\mathrm{Na}_{2} \mathrm{~S}_{2} \mathrm{O}_{3}$ 濃度が增 すとともに金の溶解量は上昇するが, $\mathrm{Na}_{2} \mathrm{~S}_{2} \mathrm{O}_{3}$ 濃度があ る濃度に達すれば，金の溶解量は一定となる。な打 $\mathrm{CuSO}_{4}$ を添加しないときは金はほとんど溶解しない。

\section{4. 考察}

この実験に扎いて生じた澱物のX線回折を行なつた結 果， $75^{\circ} \mathrm{C}$ 付近より $\mathrm{CuS}$ が生ずることを知つた。これは $\mathrm{S}_{2} \mathrm{O}_{3}{ }^{--}+\mathrm{Cu}^{++}+\mathrm{H}_{2} \mathrm{O}=\mathrm{SO}_{4}^{--}+\mathrm{CuS}+2 \mathrm{H}^{+}$ $2 \mathrm{Cu}\left(\mathrm{S}_{2} \mathrm{O}_{3}\right)_{2}-\cdots+\mathrm{O}_{2}+\mathrm{H}_{2} \mathrm{O}=2 \mathrm{~S}_{3} \mathrm{O}_{6}--+2 \mathrm{CuS}$
$+2 \mathrm{OH}^{-}$

の反応によつて生ずるものと思われる。このように $\mathrm{Cu}$ $\mathrm{S}$ が生ずるため $65^{\circ} \mathrm{C}$ をえると金板表面は黒色を呈し はじめ, $100{ }^{\circ} \mathrm{C}$ に怙いてはこれが非常に緻密に付着して いる。 $100^{\circ} \mathrm{C}$ 以上になるとこの CuS は結晶質となり, ハク離しやすく, 金板は再び溶解しはじめる。しかし140 ${ }^{\circ} \mathrm{C}$ をえると $\mathrm{S}_{2} \mathrm{O}_{3}$-- の酸化反応

$$
2 \mathrm{~S}_{2} \mathrm{O}_{3}{ }^{--}+2 \mathrm{O}_{2}=\mathrm{S}_{3} \mathrm{O}_{6}{ }^{--}+\mathrm{SO}_{4}^{--}
$$

により, $\mathrm{S}_{2} \mathrm{O}_{3}$ - 浱度が減ずるため金の溶解量は減少す る。

\section{文献}

1) Kowski : ИЗ АКАДНАУК. СССР (1957)No. 7, p. 29

2) Turin, Kakowi : ИЗ ВУЗ Цветная Металлу. (1959) №2, p. 6

3) Sinelikova, Plaksin : N3 ВУЗ Цветная Металлу. (1960) No. 5 , p. 95

4). 梅津, 户沢：日本、铈業会 昭和 39 年春季大会緷演

5) Forward, Mackiw: J. of Metals, (1955) p. 457 